International Review of Research in Open and Distributed Learning Volume 21, Number 2

April - 2020

\title{
Evaluating Pre-Service Teaching Practice for Online and Distance Education Students in Pakistan
}

Nauman Ahmed Abdullah ${ }^{1}$ and Prof. Dr Munawar Sultana Mirza ${ }^{2}$

${ }^{1}$ Lecturer (Education), Virtual University of Pakistan, ${ }^{2}$ Advisor, Virtual University of Pakistan

\begin{abstract}
In addition to conventional modes, teacher education programs in Pakistan are also offered through online and distance education. Teaching practice is a significant component of pre-service teacher education programs. Assessing the quality of teaching practice for pre-service student teachers is important, as these modules train the prospective teachers for their professional teaching careers. Virtual University of Pakistan (VU), an online university, offers pre-service teacher education programs. This research is an investigation into the learning opportunities and practices of VU student teachers in their teaching practice modules. Students enrolled in different teacher education programs served as the population of this study. Those in the fall 2018 semester who were enrolled in teaching practice modules were selected as a sample. Data sources included lesson plans prepared, lessons delivered, administrative and co-curricular duties performed by the students, as well as evaluation reports by supervisors, cooperating teachers, and school principals. There were improvements in the student teachers' lesson plan formation and their overall learning. Data obtained through personal visits by VU faculty was used to verify and assess actual classroom teaching. Lack of regular attendance and punctuality by student teachers was observed as a result. Internal review of the VU system as it relates to the teaching practice modules was conducted to address any shortcomings in the course(s), its procedures, and its controls. Recommendations for improving the system, such as grading the modules, peer-assessment, and orientation workshops for student teachers are provided, as well as suggestions for developments in the teaching practice modules themselves.
\end{abstract}

Keywords: teaching practice, evaluation, student teachers, online and distance education, pre-service teacher education programs, Pakistan 


\section{Introduction}

Teacher education (TE) institutions generally offer pre-service TE degree programs. The focus of these institutions is to achieve excellence in preparing teachers through continuous improvement and compliance with international standards. Teacher education programs provide prospective teachers a set of learning opportunities designed to help them become good teachers. However, in the pasts, there has been a dissatisfaction with the TE programs in the US, based on criticism for failing to prepare effective teachers (Darling-Hammond, 2000). In Pakistan too, concerns have been raised over the quality of TE programs. The Government of Pakistan (2007) has also expressed misgivings about the quality of TE programs. The National Education Policy (2009) emphasized the need for quality in such programs, and urged that linkages be made with various institutions to strengthen these programs further. The National Accreditation Council for Teacher Education (2009) was established by the Higher Education Commission (HEC) in Pakistan to accredit all TE programs. While there are voices of dissatisfaction and concern in Pakistan, there are also a large number of teacher education institutions actively preparing teachers (Reba \& Inamullah, 2014). These programs are running in conventional universities as well as in open and distance learning (ODL) mode. Whichever mode is used, teaching practice remains a pivotal module in such programs. Teaching practice modules are offered to prospective teachers to provide them practical experience along with theoretical knowledge. Teaching practice modules with various weightings are offered in teacher education programs worldwide.

In Nigeria, for instance, teaching practice for one semester is a compulsory part of TE programs (Aglazor, 2017). Quality of teaching practice is an essential concern of TE programs in all developed countries (Cobb, 1999; Liu, 2012). Globally, the experiences of teaching practice have been researched, particularly in relation to (a) professional grouth (b) aligning teaching practice with content courses (Liu, 2012); and (c) other allied issues such as time and classroom management (Saphier, Haley-Speca, \& Gower, 2008). Nonetheless, teaching practice serves as an integral component of initial teacher education degree programs (Mtika, 2008; Tang, 2003).

Teaching practice offers prospective teachers some practical exposure by providing experiences in actual classroom teaching. According to Surucu, Unal, and Yildirim (2017) it is obvious that the theoretical knowledge teacher candidates have received will not make sense and will not be useful unless they also encounter the knowledge, skills, attitudes, and behaviours that they will need in real educational environments. Teaching practice experience also builds student teachers' perceptions about the teaching profession (Kiggundu \& Nayimuli, 2009). One core purpose of teaching practice programs is to enable student teachers to compete globally. Teaching practice is explained in detail below.

\section{Teaching Practice}

Teaching practice is a course or module designed to enable students to apply theoretical knowledgein actual classroom settings. It provides practical experience in teaching and dealing with students, in order to foster improved practical skills (Mashile, 2008). 


\section{Cooperating Teacher}

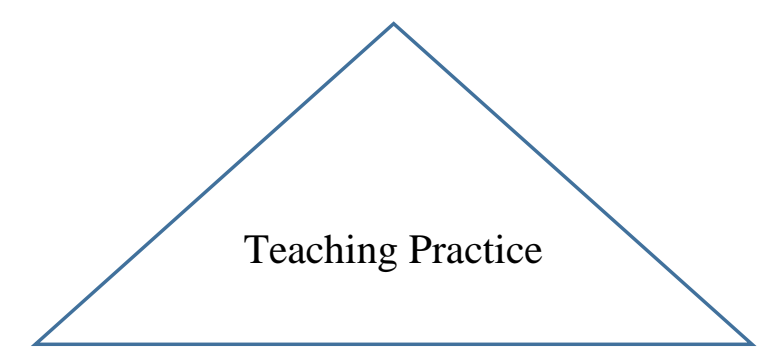

Student Teacher

University Supervisor

Figure 1. Teaching practice triad.

Teaching practice is often understood in the literature in terms of a triad. The teaching practice triad-as illustrated in Figure 1, a graphical representation of a teaching practice module-includes the cooperating teacher, university supervisor, and student teacher (Aglazor, 2017; Aglazor \&Obi, 2016).

Teaching practice influences self-efficacy and especially technology supported self-efficacy (Unal, Yamac, \& Uzun, 2017). In the literature, it is observed that student teachers frequently experience difficulties in matters such as classroom discipline, alignment in assessments, and using equipment for learning (Saritaş, 2007). Prospective teachers face various problems in converting their theoretical knowledge into teaching practice (Öksüz \& Çevik, 2014). According to Kale (2011) teaching practice gives teacher candidates the opportunity to perceive their own level of skill, correct specific mistakes, and improve their weaknesses. Methods of assessing student teachers during teaching practice is a fundamental concern, and considerable discussion on improving assessment methods is available in the literature (Yahya, Mansor, \& Abdullah, 2017). The role of the cooperating teacher is equally vital in student teachers' professional growth and development (Aglazor, 2017). These issues signify the need to evaluate the teaching practice programs that are offered to student teachers.

The purpose of evaluating any course, module, or program is to identify possible improvements, and to eliminate any irregularities (J ohnstone, 2005). Evaluating teaching practice modules is worthy of research, as it becomes the foundation of career paths for prospective teachers.

While many Organisation for Economic Co-operation and Development (OECD) countries require education degrees as an entry qualification for teachers, a few countries, however, also require that teachers pass a national test in order to attain a teaching license (OECD, 2018). In Pakistan, teachers do not need any formal licensing, though the notion is under consideration. In such conditions, it is essential to place emphasis on teaching practice in pre-service training programs, as practices followed at this stage are carried out throughout a teacher's professional career. Improvements in teaching practice need to be based on contextual research evidence. Only after incorporating contextual improvements into the modules, can the teaching practice of Pakistani universities follow international standards.

As explained, TE programs in Pakistan are also being offered through ODL. The Virtual University of Pakistan is the first and only online university in Pakistan that provides all degree programs, including teacher education, through online technologies. VU offers various HEC-recognized degree programs of 
different durations (Abdullah \& Mirza, 2018). As per the roadmap for teacher education degree programs by HEC Pakistan, the following TE degree programs are currently offered: (a) BEd (Secondary), 1.5-year program; (b) BEd (Hons), 4-year program; (c) BEd (Elementary), 2.5-year program; and (d) associate degree (ADE), 2-year program. Entrants in these degree programs must have qualifications of (a) 16, (b) 12, (c) 14, and (d) 12 years, respectively (Higher Education Commission, 2016; National Accreditation Council for Teacher Education, 2016).

The present research was undertaken to evaluate teaching practice modules for teacher education programs offered in an online educational setting. Evaluating an online degree that prepares prospective teachers for both conventional and online contexts is significant, in order to reflect upon the learning and development this mode of education offers. Hence, this research was planned to evaluate the teaching practice module of different teacher education degree programs at VU.

\section{Defining Key Terms}

In this article, the three key terms related to the teaching practice triad are used according to the following definitions.

The cooperating teacher is that teacher in the selected school whose subjects are taught by the student teacher during their teaching practice. He or she facilitates the student teacher's work and signs all their assignments before the student submits them to the university. In this paper, the term cooperating teacher may be represented by the abbreviation CT.

The university supervisor is the teacher who supervises the student teacher and checks all their teaching practice assignments and tasks.

A student teacher is the student enrolled in the teaching practice course who is doing classroom teaching in the selected school. Other names available in the literature for student teacher are aspiring teachers, prospective teachers, candidate teachers, and so on.

\section{Objectives of the Study}

The following objectives were formulated for this study:

1. To evaluate the teaching practice module in terms of the learning activities offered to the student teachers.

2. To identify shortcomings in the teaching practice modules.

3. To recommend improvements in the teaching practice modules.

\section{Methodology}

This research made use of the program evaluation technique, defined as the systematic assessment of a program's activities and outcomes in order to make judgements, improve its effectiveness, and/ or inform 
decisions about future development (Anderson \& Postlethwaite, 2011). Program evaluation in education is a process of describing a program's current situation or contributing to its development or making decisions about its policies (Yuksel, 2010). Program evaluation makes use of qualitative data, but often includes quantitative data as well (Pinch, 2009). In this mixed-methods research, qualitative and quantitative research methods were used to evaluate the TP program. Quantitative research methods helped identify the descriptive nature of the program, while qualitative research methods helped evaluate the overall program in a comprehensive way and contributed to a clear and deep understanding.

The two researchers for this study belonged to the VU faculty, and each had three years of experience at the time of the research. Together, they designed the teaching practice module and activities for TE programs at VU. Their background knowledge, understanding, and interest in the module makes them qualified for evaluating the program.

\section{Description of the Study Sample}

As explained above, VU offers teacher education programs in line with the HEC roadmap. This research was delimited to the teaching practice students and module in the fall 2018 semester only. Table 1 explains the teaching practice credits and the number of students in each teacher education degree program at the time the sample was created.

Table 1

Teaching Practice Offered to Students in Different Degree Programs at VU Fall 2018

\begin{tabular}{lcc}
\hline Degree program & Teaching practice credits & Number of students \\
\hline BEd (Hons), 4 years & 15 & 2 \\
ADE, 2 years & 6 & 10 \\
BEd (Secondary), 1.5 years & 6 & 108 \\
\hline
\end{tabular}

Due to an adequate number of students in the BEd (Secondary) 1.5-year degree program, the researchers selected this module of teaching practice only; the course code given to this module is TPT620. Hence, it was selected as the source of the sample to evaluate; 108 students were enrolled in this module in fall 2018.

\section{Data Sources}

As this was a comprehensive program evaluation, all activities planned within this course were sources of data, including

- administrative tasks related to students;

- $\quad$ students' assignments related to lesson plans;

- feedback from cooperating teacher and principal;

- monitoring visits to evaluate the student teachers' actual teaching; 
- $\quad$ student teachers' feedback on teaching practice module;

- $\quad$ student teachers' feedback on teaching practice supervisor; and

- result of all activities over the semester.

\section{Teaching Practice Module: TPT620}

TPT620 is a six-credit course offered to those entering the BEd (Secondary) 1.5-year degree program with 16 years of education. Graduates of this program enter the job market as secondary school teachers in both the public and private sector school systems. Most of the students enrolled in this program already have academic degrees in science subjects, as is required for their employment, and are enrolled in this program to gain formal teacher education degrees. Therefore, the focus of the TPT620 course is on practical assignments along with a few administrative tasks in the school. The learning opportunities and activities in this course are outlined in Table 2. A total of 24 lesson plans are required in TPT620, with two lesson plans per week in each of the three subjects the student teachers select for teaching practice. The course evaluation is based $70 \%$ on teaching activities and $30 \%$ on administrative assignments and other tasks in the school.

Table 2

List of Activities and Assessment Scheme

\begin{tabular}{|c|c|c|c|c|c|}
\hline Week & Tasks and assignments & $\mathrm{F}$ & CT comments & $\begin{array}{l}\text { Evaluation by } \\
\text { supervisor }\end{array}$ & $\begin{array}{l}\text { Marks (out of } \\
\text { 200) }\end{array}$ \\
\hline 1 & $\begin{array}{l}\text { Log of daily activities in the } \\
\text { school } \\
\text { Record of school resources } \\
\text { Interview with CT } \\
\text { Interview with student(s) } \\
\text { Community/ co-curricular } \\
\text { Engagement }\end{array}$ & $\begin{array}{l}1 \\
1 \\
1 \\
1\end{array}$ & On all & All activities & 20 \\
\hline 2 & $\begin{array}{l}\text { Observation of classroom } \\
\text { layout/ set-up } \\
\text { Observation of classroom } \\
\text { teaching } \\
\text { Observation of classroom } \\
\text { activity/ group work }\end{array}$ & $\begin{array}{l}1 \\
1\end{array}$ & On all & All activities & 20 \\
\hline & $\begin{array}{l}\text { Preparation of model lesson } \\
\text { plans (LP) }\end{array}$ & 1 & Yes & Yes & 20 \\
\hline 3 & LPs for subjects 1, 2, and 3 & 2 each & On any one & All 6 & 30 \\
\hline 4 & LPs for subjects 1,2 , and 3 & 2 each & On any one & All 6 & 30 \\
\hline 5 & LPs for subjects 1,2 , and 3 & 2 each & On any one & All 6 & 30 \\
\hline 6 & LPs for subjects 1,2 , and 3 & 2 each & On any one & All 6 & 30 \\
\hline 4 to 6 & $\begin{array}{l}\text { Assembly, debate, sports, break } \\
\text { duty, any other activity }\end{array}$ & Any 3 & Any 3 & Any 3 & 20 \\
\hline
\end{tabular}




\section{Results}

\section{Analysis of Students' Assignments to Explore Improvements in Learning}

The assignments submitted by the student teachers were approved by the cooperating teachers and school principals. Cooperating teachers gave their comments on the assignments and university supervisors marked and assigned grades to the assignments. Analysis of assignments in terms of improvement in student learning and development is displayed in Table 3.

Table 3

Evaluation of Assignments Related to Lesson Plans

\begin{tabular}{lccc}
\hline Lesson plan & \multicolumn{3}{c}{ Overall assessment of assignments } \\
\cline { 2 - 4 } assignment & Good (\%) & Satisfactory (\%) & Poor (\%) \\
\cline { 2 - 4 } 1 & 62.1 & 9.2 & 28.7 \\
2 & 59.5 & 13.1 & 27.4 \\
3 & 69.6 & 7.9 & 22.5 \\
4 & 77.7 & 6.2 & 16.1 \\
\hline
\end{tabular}

There was a total of seven assignments in the selected module. Three were related to administrative tasks a student teacher performs while doing their teaching practice in school; four were related to the preparation of lesson plans. Table 3 reflects the analysis of lesson plan assignments only. Assignments related to administrative tasks have not been included. While the lesson plan assignments were already marked by the university supervisors, for this research, they were critically reviewed against the specific criteria in a rubric designed to reassess the assignments. The rubric was comprehensive, and each section of the lesson plan (i.e., initial details, general and specific objectives, resources and materials used in teaching, procedures and details of teaching-learning activities, assignment(s) given, assessment of work/ learning, and timeallocation), was reviewed in line with the rubric criteria and assessed as poor, satisfactory, or good. After assessing each segment, researchers also gauged the overall assignment as poor, satisfactory, or good. Table 3 represents the overall percentages of weekly assignments.

Table 3 indicates that there was a distinct improvement in the students' learning. Of the week one lesson plans, $28.7 \%$ were assessed as poor, while slightly fewer (27.4\%) were rated poor in the second week. The percentage of poor assignments fell further to $22.5 \%$ in the third week. In the last week of lesson plan assignments, there was a categorical decrease in poor assignments to $16.1 \%$. Improvement of students' lesson plan assignments was clearly evident during this module. Similarly, the percentage of assignments in the good category improved from $62.1 \%$ in the first week to $77.7 \%$ in the fourth week. The increase in the good category and decrease in the poor category over four weeks of assignments is interpreted as improvement in the student teachers' learning.

\section{Monitoring Visits to Evaluate Actual Teaching by Student Teachers}

After evaluating the assigned lesson plans, monitoring visits of sample schools were made to observe and evaluate the actual teaching of student teachers. Out of the 108 students enrolled in TPT620, 15 were 
selected for a monitoring visit. As VU seeks to admit students from all over Pakistan, the total sample also represented students distributed across Pakistan. To make best use of researchers' resources, only those cities where a cluster of student teachers was available were considered for a monitoring visit. Hence, Lahore with seven students (three male and four female) and Faisalabad with eight students (three male and five female), were visited for monitoring of teaching. Findings from those visits and observations are given in Table 4.

Monitoring visits were not announced to student teachers. It was observed that eight out of fifteen students (five of the six males and three of the nine females) were not present in schools on the visit day. Moreover, the absent student teachers were not taking classes as per the schedule they had submitted to the university supervisor. It can be inferred that student teachers, particularly males, were not be taking teaching practice seriously.

Table 4

Findings From Monitoring Visits

\begin{tabular}{lcccccc}
\hline $\begin{array}{l}\text { Students' } \\
\text { gender }\end{array}$ & $\begin{array}{c}\text { School } \\
\text { type }\end{array}$ & City & $\begin{array}{c}\text { Student employment } \\
\text { status }\end{array}$ & $\begin{array}{c}\text { Present at } \\
\text { school }\end{array}$ & $\begin{array}{c}\text { Lesson plans } \\
\text { prepared }\end{array}$ & $\begin{array}{c}\text { Attending } \\
\text { scheduled } \\
\text { class }\end{array}$ \\
\hline Male & Private & Lahore & Student & No & No & No \\
Male & Private & Lahore & Student & No & No & No \\
Male & Private & Lahore & Student & No & No & No \\
Male & Public & Faisalabad & Student & No & No & No \\
Male & Public & Faisalabad & Employed in school & Yes & No & Yes \\
Male & Private & Faisalabad & Student & No & No & No \\
Female & Private & Lahore & Employed in school & Yes & Yes & Yes \\
Female & Private & Lahore & Student & No & Yes & No \\
Female & Private & Lahore & Student & No & No & No \\
Female & Public & Lahore & Employed in school & Yes & Yes & Yes \\
Female & Public & Faisalabad & Employed in school & Yes & Yes & Yes \\
Female & Private & Faisalabad & Employed in school & Yes & Yes & Yes \\
Female & Public & Faisalabad & Employed in school & Yes & Yes & Yes \\
Female & Public & Faisalabad & Employed in school & Yes & Yes & Yes \\
Female & Private & Faisalabad & Student & No & Yes & No \\
\hline
\end{tabular}

\section{Students' Opinions About Course and Supervisor}

At the end of their semester at VU, students are encouraged to give feedback on the course and the course instructor. Out of 108 students, only 43 completed the survey evaluating the TPT620 module and supervisors. Reponses were measured on a five-point Likert scale, where one represented strongly disagree and five denoted strongly agree. Table 5 reflects the evaluation feedback from TPT620 student teachers. Mean and standard deviations were calculated, along with the frequency and percentage of responses by student teachers. The TPT620 module evaluation form consisted of a series of items grouped by three particular factors, with a maximum possible score of five for each item. The factors comprised: (a) student contribution ( $\mathrm{M}=4.37, \mathrm{SD}=.79)$; (b) learning resources $(\mathrm{M}=4.17, \mathrm{SD}=.91)$; and (c) evaluation $(\mathrm{M}=4.23$, 
$\mathrm{SD}=$.74). All items in this evaluation had a mean score above 4.0 showing a high level of agreement (satisfaction) among students.

Table 5

Student Teachers Evaluation of the TPT620 Module

\begin{tabular}{|c|c|c|c|}
\hline Factor & Item & $\mathrm{M}$ & $\mathrm{SD}$ \\
\hline \multirow{5}{*}{$\begin{array}{l}\text { Student } \\
\text { Contribution }\end{array}$} & & 4.37 & .79 \\
\hline & & & \\
\hline & $\begin{array}{l}\text { I participated actively in the course through e-mail, Moderated } \\
\text { discussion boards, Skype/ TeamViewer sessions. }\end{array}$ & 4.19 & .89 \\
\hline & I think I have completed my internship within prescribed time. & 4.40 & .71 \\
\hline & $\begin{array}{l}\text { I performed my internship with honesty and fulfilled all course } \\
\text { requirements. }\end{array}$ & 4.42 & .78 \\
\hline \multirow{5}{*}{$\begin{array}{l}\text { Learning } \\
\text { Resources }\end{array}$} & & 4.17 & .91 \\
\hline & & & \\
\hline & $\begin{array}{l}\text { The learning material (e.g., semester plan, internship report } \\
\text { guidelines) were relevant and useful. }\end{array}$ & 4.16 & .91 \\
\hline & $\begin{array}{l}\text { The provision of learning resources in the e-library is adequate } \\
\text { and appropriate. }\end{array}$ & 4.19 & .81 \\
\hline & $\begin{array}{l}\text { The provision of learning resources (e.g., FAQs, glossary, } \\
\text { important URLs) is adequate and appropriate. }\end{array}$ & 4.09 & 1.0 \\
\hline \multirow[t]{7}{*}{ Evaluation } & & 4.23 & .74 \\
\hline & $\begin{array}{l}\text { The method of evaluating internship report submissions is } \\
\text { reasonable and fair. }\end{array}$ & 4.23 & .88 \\
\hline & $\begin{array}{l}\text { Feedback on different internship report submissions is well- } \\
\text { timed. }\end{array}$ & 4.28 & .58 \\
\hline & Feedback on different internship report submissions is helpful. & 4.16 & .80 \\
\hline & Consistency and uniformity are observed during evaluation. & 4.35 & .56 \\
\hline & $\begin{array}{l}\text { The instructor clearly communicates the assessment activities } \\
\text { and evaluation criteria. }\end{array}$ & 4.19 & .84 \\
\hline & $\begin{array}{l}\text { The evaluation of my documents (e.g., internship completion } \\
\text { certificate [ICC]) is logical. }\end{array}$ & 4.16 & .77 \\
\hline
\end{tabular}


Table 6

Student Teachers' Evaluation of Supervisor

\begin{tabular}{|c|c|c|c|}
\hline Factor & Item & $\mathrm{M}$ & SD \\
\hline \multirow{4}{*}{$\begin{array}{l}\text { Guidance by } \\
\text { supervisor }\end{array}$} & & 4.13 & .89 \\
\hline & & & \\
\hline & $\begin{array}{l}\text { Supervisor guides me and provides a clear track to complete my } \\
\text { teaching practice. }\end{array}$ & 4.23 & 0.83 \\
\hline & $\begin{array}{l}\text { Supervisor guides me in preparing oral presentation of teaching } \\
\text { practice. }\end{array}$ & 4.02 & 0.95 \\
\hline \multirow{4}{*}{$\begin{array}{l}\text { Interaction with } \\
\text { supervisor }\end{array}$} & & 4.14 & .85 \\
\hline & $\begin{array}{l}\text { Supervisor continuously interacts with me to keep my } \\
\text { motivation high. }\end{array}$ & 4.16 & 0.96 \\
\hline & $\begin{array}{l}\text { Supervisor is always available through e-mail, MDB, or Skype to } \\
\text { address my problems. }\end{array}$ & 4.23 & 0.67 \\
\hline & $\begin{array}{l}\text { While conducting Skype sessions, supervisor demonstrates } \\
\text { knowledge of the subject. }\end{array}$ & 4.02 & 0.92 \\
\hline \multirow{5}{*}{$\begin{array}{l}\text { Module-related } \\
\text { support by } \\
\text { supervisor }\end{array}$} & & 4.20 & .74 \\
\hline & $\begin{array}{l}\text { Reply to queries through e-mail or MDB reflects supervisor's } \\
\text { command of the subject. }\end{array}$ & 4.19 & 0.81 \\
\hline & $\begin{array}{l}\text { Supervisor returns teaching practice submissions in a reasonable } \\
\text { amount of time. }\end{array}$ & 4.21 & 0.63 \\
\hline & $\begin{array}{l}\text { Supervisor helps me search for a suitable institution for my } \\
\text { teaching practice. }\end{array}$ & 4.00 & 0.98 \\
\hline & $\begin{array}{l}\text { The deadlines set by my supervisor for teaching practice } \\
\text { submissions are appropriate. }\end{array}$ & 4.40 & 0.53 \\
\hline
\end{tabular}

Table 6 presents the responses of student teachers in evaluating their teaching practice supervisors. The supervisor evaluation also reflected a mean score for each item above 4.0, suggesting high levels of student satisfaction with their supervisors. These items were further grouped into factors such as: (a) guidance by supervisor ( $\mathrm{M}=4.13, \mathrm{SD}=.89)$; (b) interaction with supervisor ( $\mathrm{M}=4.14, \mathrm{SD}=.85)$; and (c) module-related support by supervisor ( $\mathrm{M}=4.20, \mathrm{SD}=.74$ ). The analysis of both evaluation surveys (Tables 5 and 6 ) displayed high agreement among student teachers on all items, which can be interpreted as student teachers' high level of satisfaction with the module and the module supervisor.

\section{Overall Results of the TPT620 Module}

Out of the sample of 108 students, 90 achieved a pass and the remaining 18 were assessed a fail. The failed students submitted fewer than four assignments out of the seven required. In fall 2018, it was noted that the TP module was not graded, as it was a qualifying course only. Recommendations are given on the final result of students of this module on the basis of overall program evaluation by the researchers. 


\section{Discussion and Recommendations}

This section presents a critical discussion of the findings of the TPT620 module evaluation in terms of how the study's research objectives were achieved.

\section{Research Objective One: Evaluating the TPT620 Learning Activities}

The complete module was reviewed and evaluated. The researchers analyzed all the components and activities planned throughout the course module. Data from different sources were gathered by making formal requests to the concerned departments such as administration and examination, as aligned with the ethical considerations of this study. Assignments from 108 students were reviewed and assessed again. Monitoring visit reports were analyzed and compiled to review the findings. Feedback given to student teachers on classroom teaching during monitoring visits was also reviewed. Module evaluation and supervisor evaluation forms were also analyzed and interpreted. In addition, the course related directions given to the students by the department of education from time to time were critically reviewed and possible improvement opportunities were explored. Anderson and Postlethwaite (2011) suggested that a comprehensive program evaluation in education studies calls for rigorous analysis of all the program's segments, so different components of the TPT620 module were analyzed for this evaluation. To achieve this first objective, this research explored the improvements in student teachers' learning and development as they participated in teaching practice modules.

After assessing the assignments, such improvements were seen; Table 3 reflects a significant increase in the assignments assessed as good, and a considerable decrease in the assignments assessed as poor. However, it cannot be ascertained whether students, by improving their theoretical assignments, can actually perform well in the practical field. Researchers considered this a limitation of the study; it would be useful to determine how many student teachers are employed, promoted, or receive a salary increment on the basis of this degree program. Darling-Hammond (2000) suggested that attaining an initial teacher education degree increases the chances of having a stable teaching career. A follow-up study to explore student teachers' career opportunities might help determine the actual learning and development achieved through the module.

In monitoring visits, the students were also given feedback on their teaching styles. Students who were present during the visits were evaluated for their teaching skills on a checklist to assess factors such as: (a) student teacher's personal traits, (b) classroom teaching, (c) classroom management, (d) classroom engagement, and (e) quality of teaching. However, in the fall 2018 semester, no outcomes of that evaluation were seen, since the teaching practice was not only non-graded because it did not contribute to students' final results. Follow-up monitoring visits should be made to review any improvements in students' classroom teaching. Other mechanisms of recurrent feedback on classroom teaching should be established after the monitoring visit, such as evaluation of teaching by cooperating teacher or peer-assessment, when there is more than one student teacher in the school. Previously, video recording student teachers' lectures was not successful at VU, as every student could not afford a smart mobile phone, and at times the resulting video and audio quality was also substandard. Therefore, alternate ways to assess performance need to be 
identified, as literature indicates that monitoring students' teaching practices motivates and helps them improve (Aglazor, 2017; Unal, Yamac, \&Uzun, 2017).

A workshop on a group of student teachers can be conducted before the start of TP modules, to familiarize them with the course requirements and learning outcomes. At VU, learning outcomes might be improved if workshops can be added. Allama Iqbal Open University (AIOU), another distance education university in Pakistan, organizes workshops for teaching practice students. A study of their practices might be useful for other ODL institutions, including VU. Therefore, a small level study is suggested by the researchers to evaluate the usefulness of such workshops at AIOU.

The results of evaluating the teaching practice module and supervisors indicated that students were mostly satisfied with the module and the supervisors. However, VU should review its student evaluation form and make it more specific to the TP module. VU should also consider adding international standards and practices to the TP module, and make the supervisors' role more practical (Kale, 2011).

\section{Research Objective Two: Identifying Shortcomings in TPT620}

During the evaluation of assignments other than lesson plans, it was observed that student teachers submitted timetables in various formats. VU should develop a standard timetable format for all student teachers to adhere to. Even though different schools might follow their own timetable format, student teachers could still develop their to follow the prescribed format, to be signed by the schools' authorities. Johnstone (2005) suggested that uniformity in all activities ensures transparency and merit in assessment. One shortcoming noticed during the TP evaluation was that student teachers' attendance was not monitored. Supervisors did not know whether the student teachers are actually going to the school regularly and punctually.

Another shortcoming observed was the student teachers already on the job did not comply with the teaching practice schedule of VU; instead, they followed their scheduled classes in the schools, other than secondary level classes, as per job requirements. Those who work in the same school they select for teaching practice should be asked to select and teach secondary level classes like other students as per degree requirements. United Nations Educational, Scientific and Cultural Organization (2002) encouraged that teaching practice take place at the same level the student teacher's career path, or similar to the requirements of the degree program. Other ways of ensuring the teaching practice at required level shall also be considered. Further, it was found that there were no follow-up monitoring visits; only one visit was made. The evaluation of classroom teaching was not included in the final outcome of the module. The reasons for this exclusion are obvious - as only sample students were monitored, making this evaluation a part of the final assessment does not fit well. However, VU's education department and leadership, as well as other ODL institutions, should consider ways to include teaching evaluation as part of the final assessment. As Mayes and Burgess (2011) have stated, teaching practice needs to be monitored, especially in ODL, in order to achieve learning outcomes effectively. Physical monitoring of teaching practice is not practically possible given that students are dispersed across Pakistan, therefore the use of information communication and technology is suggested. As well, student teachers might visit the campuses in their area in order that a sample model lecture, either live or recorded, can be evaluated. 


\section{Research Objective Three: Improving the Teaching Practice Module}

In order to recommend improvements in VU's teaching practice modules, consolidated analyses of all data sets were done. The findings were reviewed and discussion points were raised. Researchers offer the following recommendations for improvement, as a result of this research.

The subjects that student teachers opt to teach in the schools must relate to the specialization subjects of their previous academic qualifications. This will align their previous academic qualifications and their classroom teaching, thus strengthening the content and control in their teaching. It is recommended that TP modules should be graded in pre-service teacher education programs to better reflect students' learning outcomes and achievements. Orientation workshops should be organized for student teachers, to achieve a twofold purpose. First, student teachers will come to understand the mechanism of teaching practice, and their questions might be addressed. Second, training could be offered on topics such as lesson planningand classroom management. Similarly, other ODL institutions that offer or intend to offer teaching practice should also incorporate this suggestion in their modules.

Student teachers' school selection could be improved. The preference, while selecting the schools, should be given to public sector schools. For private schools, a minimum number of students in the secondary level, perhaps 20, students should be added as a criterion. This would broaden student teachers' classroom teaching experience because, in public sector schools, the number of pupils in classes is high and classes are scheduled daily. Selecting a private sector school with at least 20 students in the secondary classes might also enhance the learning environment for student teachers. Peer assessment of student teachers might be considered, as a strategy for continuous improvement. Student teachers' attendance and punctuality can be emphasized and monitored if every document submitted by the student teacher is countersigned by their cooperating teacher and school principal. Another option could be a weekly attendance report duly signed by the cooperating teacher and principal. At the time of school selection, supervisors should contact the school principals and ensure that the student teachers have provided the original information about school, classes, timetable, and schedule. Practices of other ODL institutions across the globe need to be studied to help create a comprehensive policy for Pakistan. Making such reforms and improvements in the teaching practice module might help improve students' practice, as well as the module's learning and developmental outcomes. Similarly, the practices and evaluation of the TPT620 module in this research might help other developing countries initiate TE programs and set quality standards in teaching practice modules.

\section{Conclusions}

By analyzing the TP module and summarizing the discussion points it was concluded that overall, the students were satisfied with the teaching practice module and role of supervisors in conducting teaching practice at VU. It is further concluded that for continuous improvement, ODL institutions should consider recurrent feedback from student teachers in teaching practice modules. Student teachers improved their 
lesson planning, which might be attributed to the learning activities in the teaching practice module. Therefore, it is clear that a mix of activities should be offered to student teachers as assignments in teaching practice modules to foster their learning. After evaluating the complete module, it is evident that despite a few possible improvement opportunities, the teaching practice offered in various degree programs at VU is striving to achieve its learning outcome of improving students' practical experience and learning. This teaching practice module enables student teachers to develop classroom preparation skills, includinglesson planning. In their TP modules, other ODL institutions can improve student teachers' classroom management by offering strict monitoring of their classroom teaching. This evaluative study is useful as a case study for initiating and evaluating teaching practice modules in ODL institutions around the world. 


\section{References}

Abdullah, N.A., \& Mirza, M.S. (2018). Entry qualifications of students as predictors of academic performance in various degree programs in distance education setting in Pakistan. Open Praxis, 10(3), 237-247. http:// dx.doi.org/ 10.5944/ openpraxis.10.3.848

Aglazor, G. (2017). The role of teaching practice in teacher education programmes: Designing framework for best practice. Global J ournal of Educational Research, 16(2), 101- 110. http:// dx.doi.org/ 10.4314/ gjedr.v16i2.4

Aglazor, G. N., \& Obi, F. B. (2016). Teaching practice handbook for programmers, students and supervisors. Calabar, Nigeria: University of Calabar Press.

Anderson, L. W., \& Postlethwaite, T. N. (2011). Program evaluation: Large scale and small scale studies. Education policy series. Paris, France: International Institute for Educational Planning.

Cobb, V. L. (1999). An international comparison of teacher education (ERIC Digest: ED436486). Washington DC: ERIC Clearinghouse on Teaching and Teacher Education.

Darling-Hammond, L. (2000). How teacher education matters. J ournal of Teacher Education, 51(3), 166- 173. https:// doi.org/ 10.1177/ 0022487100051003002

Government of Pakistan. (2007). Revised white paper on education in pakistan. Islamabad group on education. Islamabad; Planning Commission.

Higher Education Commission. (2016). Notification on teacher education roadmap. Islamabad, Pakistan: Higher Education Commission.

J ohnstone, A. (2005). Evaluation of teaching: A physical science practice guide. Hull, UK: Higher Education Academy, Physical Science Centre. Retrieved from https:// www.heacademy.ac.uk/ system/files/ps0073_evaluation_of_teaching_oct_2005.pdf

Kale, M. (2011). Problems encountered in teaching practice of teachers' course. Turkish J ournal of Educational Sciences, 9(2), 255- 280. https:// dergipark.org.tr/ en/ download/ article-file/ 256212

Kiggundu, E., \&Nayimuli, S. (2009). Teaching practice: A make or break phase for student teachers. South African J ournal of Education, 29(3), 345- 358. http:// dx.doi.org/ 10.15700/ saje.v29n3a129

Liu, P. (2012). Student teaching practice in two elementary teacher preparation programs. Australian J ournal of Teacher Education, 37(1) 14-34. Retrieved from https:// ro.ecu.edu.au/ajte/ vol37/iss1/ 8/

Mashile, E. (2008). Supply and demand for teachers: Is open and distance learning the answer? Africa Education Review, 5(2), 351- 363. https:// doi.org/ 10.1080/ 18146620802450058 
Mayes, A. S., \& Burgess, H. (2011). Open and distance learning for initial teacher education. In P.A. Danaher \&A. Umar (Eds.), Perspectives on distance education: Teacher education through open and distance learning (pp. 35- 46). Vancouver, BC: Commonwealth of Learning.

Mtika, P. D. G. (2008). Teaching practice as a component of teacher education in Malawi: An activity theory perspective (Doctoral thesis, University of Nottingham, Nottingham, England). Retrieved from http:// eprints.nottingham.ac.uk/id/ eprint/ 10526

National Accreditation Council for Teacher Education. (2009). National standards for accreditation of teacher education program. Islambad, Pakistan: National Accreditation Council for Teacher Education. Retrieved from http:// www.nacte.org.pk/Download/National_Standards_for_Accreditation.pdf

National Accreditation Council for Teacher Education. (2016). Teacher education roadmap. Islamabad, Pakistan: National Accreditation Council for Teacher Education. Retrieved from: http:// www.nacte.org.pk/\#/ eventsnews/TeacherEducation/Roadmap

National Education Policy. (2009). 2009- 2015 Educational policy. Islamabad, Pakistan: Ministry of Education, Government of Pakistan.

Organisation for Economic Co-operation and Development. (2018). Education at a glance 2018: OECD indicators. Paris, France: OECD Publishing. https:// doi.org/10.1787/ eag-2018-en

Öksüz, Y., \& Çevik, C. (2014). Evaluation of prospective teachers and practice classroom teachers opinions of problems encountered in practice schools (Bayburt University sample). Procedia - Social and Behavioral Sciences, 116, 2909- 2914. doi: 10.1016/j.sbspro.2014.01.678

Pinch, K. J . (2009). The importance of evaluation research. J ournal of Experiential Education, 31(3), 390- 394. https:// doi.org/ 10.1177/ 105382590803100306

Reba, A., \& Inamullah, H. M. (2014). Perceptions of teacher educators' regarding teacher education program in KPK Pakistan. Bulletin of Education and Research, 36(2), 1- 12. Retrieved from http:// pu.edu.pk/images/journal/ier/ PDFFILES/ 1 Amjad\%20and\%20Inamullah.pdf

Saphier, J ., Haley-Speca, M. A., \& Gower, R. R. (2008). The skillful teacher: Building your teaching skills (6 $6^{\text {th }}$ edition). Acton MA: Research for better teaching, Inc.

Sarıtaş, M. (2007) okul deneyimi I uygulamasının aday öğretmenlere sağladığı yararlar konusundaki görüsslerin değerlendirilmesi [Evaluation of school experience: Implementation of views on the benefits to student teachers]. Uludağ University Journal of Faculty of Education, 20(1), 121- 143.

Surucu, A., Unal, A., \& Yildirim, A. (2017). Evaluation of teaching practice course teachers according to opinions of math teacher candidates. International J ournal of Research in Education and Science, 3(1), 107- 113. 
Tang, S. (2003). Challenge and support: The dynamics of student teachers' professional learning in the field experience. Teaching and Teacher Education, 19, 483-498. Doi: 10.1016/S0742$\underline{051 X(03) 00047-7}$

Unal, E., Yamac, A., \&Uzun, A. M. (2017). The effect of the teaching practice course on pre-service elementary teachers' technology integration self-efficacy. Malaysian Online J ournal of Educational Technology, 5(3), 39- 53. Retrieved from https:/ / eric.ed.gov/ ?id=EJ 1150409

United Nations Educational, Scientific and Cultural Organization. (2002). Teacher education guidelines: Using open and distance learning- technology, curriculum, cost, evaluation. Paris, France: United Nations Educational, Scientific and Cultural Organization.

Yahya, S. A., Mansor, R., \& Abdullah, M. H. (2017). Analysis of teaching practice assessment methods for pre-service teachers. International J ournal of Academic Research in Business and Social Sciences, 7(3), 890- 903. doi: 10.6007/IJARBSS/v7-i3/2957

Yuksel, I. (2010). How to conduct a qualitative program evaluation in the light of Eisner's educational connoisseurship and criticism model. Turkish Online J ournal of Qualitative Inquiry, 1(2), 78- 83. Doi: $\underline{10.17569 / \text { tojqi. } 70817}$

\section{Athabasca University}

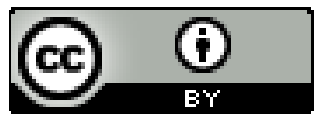

